Research Article

\title{
Stress Relief and Stimulation of Coal Reservoir by Hydraulic Slotting
}

\author{
Xiaoyang Cheng $\mathbb{D}^{1,2}$ Qinghua Zhang, ${ }^{1,2}$ Zhigang Zhang $\mathbb{D}^{1,2}$ Yunlong Zou, ${ }^{1,2}$ \\ and Guo Junjie ${ }^{3}$ \\ ${ }^{1}$ China Coal Technology Engineering Group Chongqing Research Institute, Chongqing 400037, China \\ ${ }^{2}$ State Key Laboratory of Gas Disaster Monitoring and Emergency Technology, Chongqing 400037, China \\ ${ }^{3}$ School of Safety Engineering, Henan Institute of Engineering, Zhengzhou 451191, China \\ Correspondence should be addressed to Zhigang Zhang; zzg-2@163.com
}

Received 20 December 2020; Revised 23 January 2021; Accepted 27 February 2021; Published 20 April 2021

Academic Editor: Chi Yao

Copyright (c) 2021 Xiaoyang Cheng et al. This is an open access article distributed under the Creative Commons Attribution License, which permits unrestricted use, distribution, and reproduction in any medium, provided the original work is properly cited.

Coal seam permeability is one of the key factors influencing the gas extraction efficiency, which is of great significance to reduce coal and gas dynamic disasters in gassy coal mines. Hydraulic slotting technique is an effective method to stimulate the coal reservoir, but the selection of slotting key parameters has great impact on gas extraction efficiency. For this reason, the hydraulic slotting model was established by using FLAC ${ }^{3 \mathrm{D}}$ software to analyze the stress distribution before and after slotting. Then, the influence of borehole diameter, slotting width, and slotting length on coal seam stress relief is also discussed. The results show that the slotting width has a great influence on the stress relief of the coal seam, while the borehole diameter and slotting length have no obvious influence on that. Based on the results of numerical simulation, field tests were carried out in Sangshuping NO.2 coal mine. The results show that the coal seam stress can be fully released, resulting in the improvement of coal seam permeability. The gas extraction efficiency can be highly enhanced by hydraulic slotting. This research achievement provides the guidance basis for high-stress water jet slotting technology with adaptive selection of slotting parameters in different geological conditions.

\section{Introduction}

As the most important energy in China, coal plays an important role in promoting China's economic development [1]. In order to realize the maximum utilization of resources in the coal production process, the resource exploitation model of "coal-gas coexploitation" has been formed in China $[2,3]$. However, China's coal reservoir has common characteristics such as high gas content, high gas stress, and low permeability, which also results in low production of coalbed methane and difficulties in large-scale development. In addition, the low efficiency of gas drainage is also the direct cause of increasing the frequency of gas dynamic disasters $[4,5]$. To improve the efficiency of gas extraction, experts and scholars at home and abroad have been putting lots of effort in permeability improvement in the coal reservoir. The widely applied techniques to improve the permeability of the coal seam include deep-hole split blasting [6-8], hydraulic slotting [9-12], hydraulic fracturing [13, 14], hydraulic flushing [15-17], $\mathrm{CO}_{2}$ fracturing [18-20], and gas injection $[21,22]$. Different techniques are all able to create a large number of fractures, forming a network of fractures that can promote the gas migration. However, the adaptability of different techniques to the occurrence conditions of the coal seam is different to some extent.

Hydraulic slotting technology is being developed rapidly in recent years, which cannot only weaken or eliminate the danger of gas disasters but also change the physical property of the coal reservoir to realize the double effect of stress relief and permeability enhancement in the coal seam. Therefore, this technology has been widely used in coal mines. Yang et al. [23] have put forward a method using high-pressure water jet technology to control rock burst in roadway and analyzed the theory of controlling rock burst in roadway by the weak structure zone mode. Then, the influence law of the weak structure zone under dynamic and static-combined 
load is analyzed by the numerical simulation method. The results show that the distressed zone formed by highpressure water jet cutting seam can effectively prevent rock burst. Zhang et al. [24] and Yin et al. [25], respectively, used experimental and simulation methods to study the prevention and control mechanism of high-pressure water jet slicing on rock burst. Feng [26] and Lu et al. [27] studied the application of hydraulic slotting technology in rock crosscut uncovering coal. The results show that hydraulic slotting technology has significant advantages in improving the gas drainage effect and shortening the time of coal uncovering at cross-cut, and the application of hydraulic slotting technology in tunnel coal uncovering engineering also proves this conclusion [28]. Lin et al. [29] and Chen et al. [30] applied the hydraulic slotting technology to the outburst prevention in the excavation working face, and the field test proved that the hydraulic slotting technology has good pressure relief and permeability increasing effect and has a positive role in reducing or eliminating the outburst risk of the coal mine. These research results provide a large number of reference examples for the promotion and application of hydraulic slotting technology in coal mines.

For hydraulic slotting technology, the selection of slotting parameters has a significant effect on the stress relief effect of the coal seam. Wei [31] simulated the formation of the stress relief area by hydraulic slotting utilizing PFC2D software and concluded that the effective slotting radius of the coal seam was $0.5 \mathrm{~m}$ and optimal hole spacing was $5 \mathrm{~m}$. Lu et al. [32] pointed out that, in the same seam, the optimal distance between the slots is $4 \mathrm{~m}$. Zhang and Zou [33] and Cheng et al. [34] established the prediction model of slotting depth and verified its precision in the field test. Si et al. [35] discussed the influence of geological mechanical property, in situ stress, slotting shape, slotting spacing, and other key parameters on slotting performance. $\mathrm{Lu}$ et al. [36, 37] studied the influence of slotting parameters on fracture closure of soft and hard coal after slotting. The spacing between boreholes is also an important part of slotting parameters, and the spacing between boreholes is directly related to the gas extraction radius after slotting. Xue et al. [38] adopted a thermo-hydro-mechanical coupled model to study the influence of hydraulic slotting technology on the gas extraction radius. Ge et al. [39] used COMSOL software to study the drainage influence radius of the slotted borehole in different coal seam conditions, and field tests were carried out.

The hydraulic slotting technology first increases the fracture opening generated by the release of the stress of the coal seam. Then, under the effect of stress, the fracture gradually closes, which results in the reduction of permeability of the coal seam [40]. How to preserve the high permeability of the coal seam and how to extend the period of high gas extraction efficiency are the core issues of the development of hydraulic slotting technology. Thus, the scientific selection of slotting parameters is crucial. In this paper, FLAC ${ }^{3 D}$ numerical simulation software is used to simulate hydraulic slotting. Firstly, the stress relief effect of the coal around the borehole before and after the slotting is discussed. Secondly, the influence of the slotting parameters on the stress relief effect of the coal seam is analyzed. Finally, based on the guidance of numerical simulation results, the hydraulic slotting field test is carried out to verify the improvement of gas extraction by hydraulic slotting. This study provides the theoretical support for the optimization of slotting process and high-efficiency gas extraction.

\section{The Influence of Hydraulic Slotting on Stress Relief of the Coal Seam}

2.1. Model Establishment and the Governing Equation. After the formation of the slotting borehole, stress concentration will happen around the borehole. After slotting, the coal around the borehole damages and deforms, which results in the stress relief. In order to study the influence of slotting on the stress relief of the coal seam around the borehole, this paper chooses the coal seam as the research object and adopts Fast Lagrangian Analysis of Continuous numerical simulation to study the stress distribution around the borehole before and after slotting and then study the impact of different slotting parameters on the stress relief effect by hydraulic slotting. The simulation parameters are based on the test results of physical and mechanical parameters of No. 3 coal in Sangshuping NO.2 coal mine, as shown in Table 1.

The simulation adopts the two-dimensional model, with size $8 \mathrm{~m} \times 5 \mathrm{~m}$ and a diameter of $100 \mathrm{~mm}$. Symmetrical slotting is conducted along the center of the borehole to both sides, with division into 3538 units in total by $58 \times 61$, and all units are quadrilateral equal units. The grid around the slots is refined. Taking the far-field effect into consideration, the grid is divided with a combination of equal and unequal spacing. The left edge of the model adopts the symmetric boundary, and the right edge adopts the displacement boundary. The left and right edges only allow the boundary nodes to move along the vertical direction. The lower edge is set as the displacement boundary, of which the horizontal and vertical displacements are both zero. The upper edge adopts the stress boundary, and the applied vertical stress is $0.6 \mathrm{MPa}$. In order to simulate the effect of hydraulic slotting, a flat slotting with a length of $90 \mathrm{~mm}$ and a width of $60 \mathrm{~mm}$ is formed along the center of the borehole. The grid model is shown in Figure 1. After the model is established, the center of the borehole is marked as the origin of coordinates, and the stress and displacement value of all the points on $X=2 \mathrm{~cm}$ and $Y=2 \mathrm{~cm}$ measuring lines are recorded by using the FLAC print command. The calculation process of the model can be seen from Figure 2. Firstly, the appropriate mathematical model and geometric model should be established according to the problem and then mesh the geometric model Then, the model boundary conditions should be initialized. Then, calculate the initial conditions to see if the results are reasonable. If the calculation result is not reasonable, then return to Step 1 to find the problem. If the result is reasonable, then calculate the problem under predetermined conditions to see if the result is reasonable. If not, return to Step 1, and gradually check whether there is a problem in each step and modify it. If reasonable, the calculation is completed, and the data can be exported and postprocessed. 
TABLe 1: Simulation parameters' form.

\begin{tabular}{lcc}
\hline Parameter & Minimum-maximum value & Mean value \\
\hline Wave velocity $(\mathrm{m} / \mathrm{s})$ & $1974 \sim 2245$ & 2105 \\
Vision density $\left(\mathrm{kN} / \mathrm{m}^{3}\right)$ & $13.40 \sim 14.13$ & 13.36 \\
Uniaxial compression strength $(\mathrm{MPa})$ & $12.74 \sim 16.00$ & 14.64 \\
Uniaxial elastic modulus $(\mathrm{GPa})$ & $3.64 \sim 3.91$ & 3.79 \\
Uniaxial deformation modulus $(\mathrm{GPa})$ & $2.61 \sim 2.92$ & 2.81 \\
Poisson's ratio & $0.37 \sim 0.42$ & 0.39 \\
Consistent coefficient & $1.3 \sim 1.6$ & 1.5 \\
Cohesive force $(\mathrm{MPa})$ & - & 10.13 \\
Internal friction angle $\left({ }^{\circ}\right)$ & - & 30.7 \\
\hline
\end{tabular}

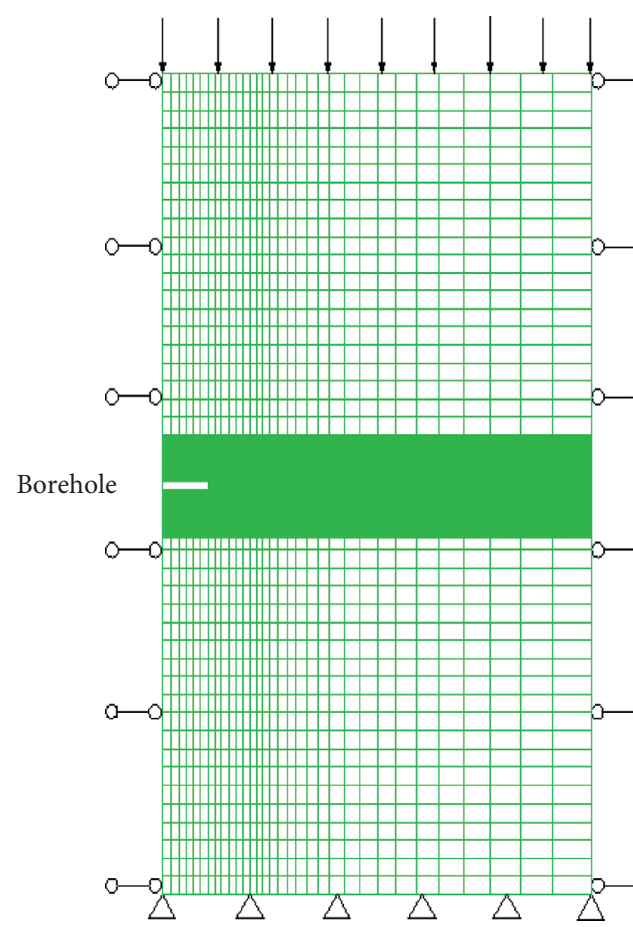

(a)

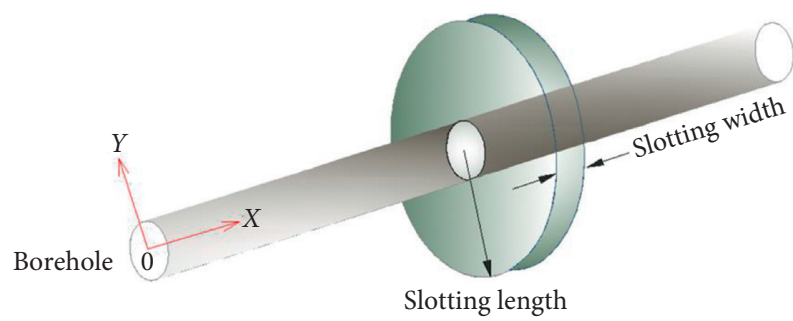

(b)

FIgURE 1: Grid model and slotting schematic.

The calculation of the model needs to consider the following assumptions: (1) the model is subject to three-dimensional static equilibrium conditions; (2) the rock is a homogeneous isotropic elastic-plastic continuum medium; (3) the rock mass in the plastic zone meets the Mohr-Coulomb strength criterion. The governing equation calculated by the model is as follows [41].

2.1.1. Stress-Strain Equation. When the model causes small plastic strains, the stress-strain relationship is then written as

$$
\sigma=\sigma_{0}+C^{\prime}:\left(\varepsilon-\varepsilon_{0}-\delta \theta\right),
$$

where $\sigma$ is the Cauchy stress tensor, $\sigma_{0}$ and $\varepsilon_{0}$ are the stress and strain tensors, $\varepsilon$ is the total strain tensor, $\delta$ is the thermal expansion tensor, and $C^{\prime}$ is the fourth-order elasticity tensor. Due to the thermal effect being neglected, $\delta \theta=0$.

According to the deformation continuity condition, the total strain tensor is written in terms of the displacement gradient:

$$
\varepsilon=\frac{1}{2}\left[\left(\frac{\partial s}{\partial x}+\frac{\partial s}{\partial y}\right)+\left(\frac{\partial s}{\partial x}+\frac{\partial s}{\partial y}\right)^{T}\right],
$$

where $s$ is the displacement.

\subsubsection{Mohr-Coulomb Strength Criterion.}

$$
|\tau|=C+\sigma \tan \varphi,
$$

where $\tau$ is the shear stress, $C$ is the cohesive force, and $\varphi$ is the angle of internal friction.

2.2. The Stress Distribution of the Surrounding Rock around the Borehole before and after Slotting. Figure 3 shows the vertical stress distribution on $X=2 \mathrm{~cm}$ and $Y=2 \mathrm{~cm}$ measured lines before and after slotting. From Figure 3(a), after the formation of the borehole, the vertical stress on $X=2 \mathrm{~cm}$ measured line will decrease gradually in radiation from the 


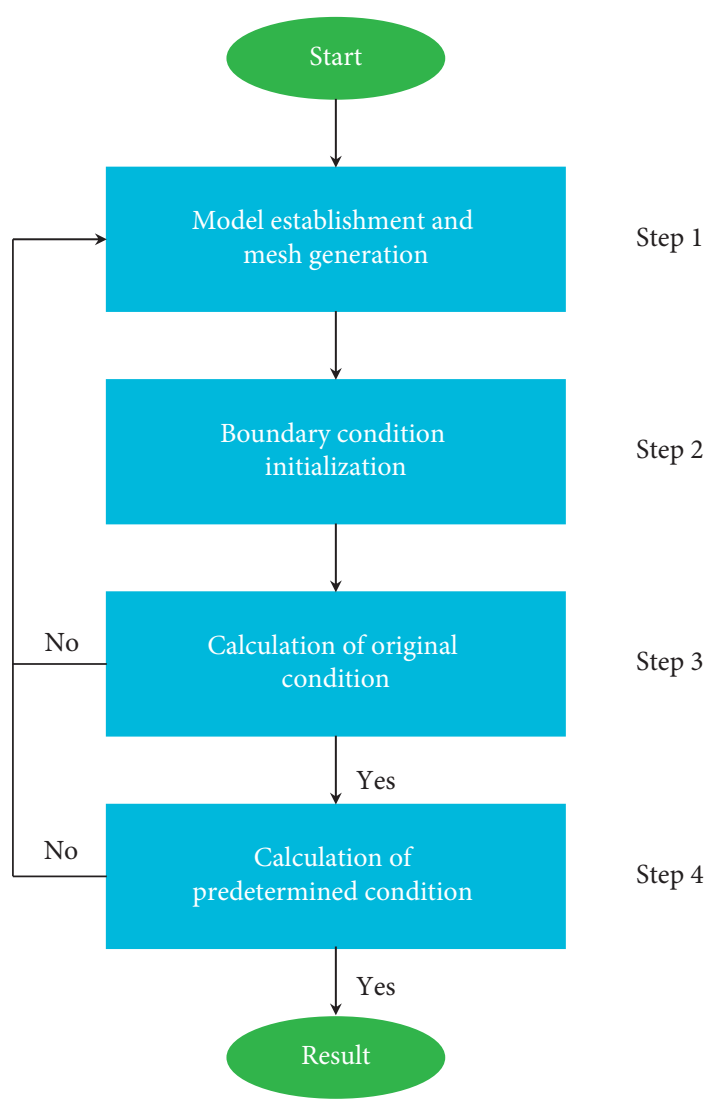

FIgURE 2: Calculation process of FLAC3D.

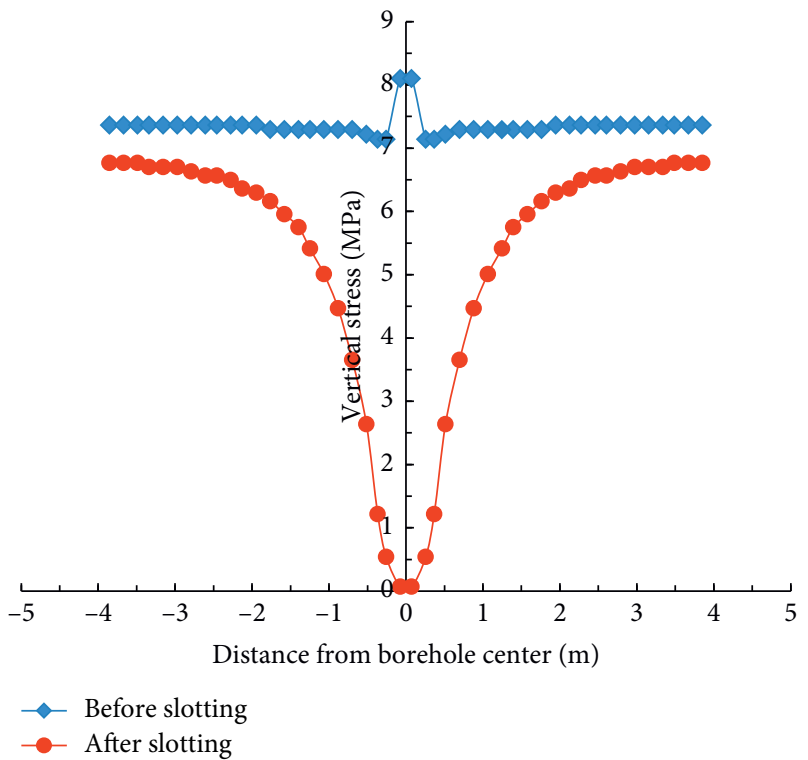

(a)

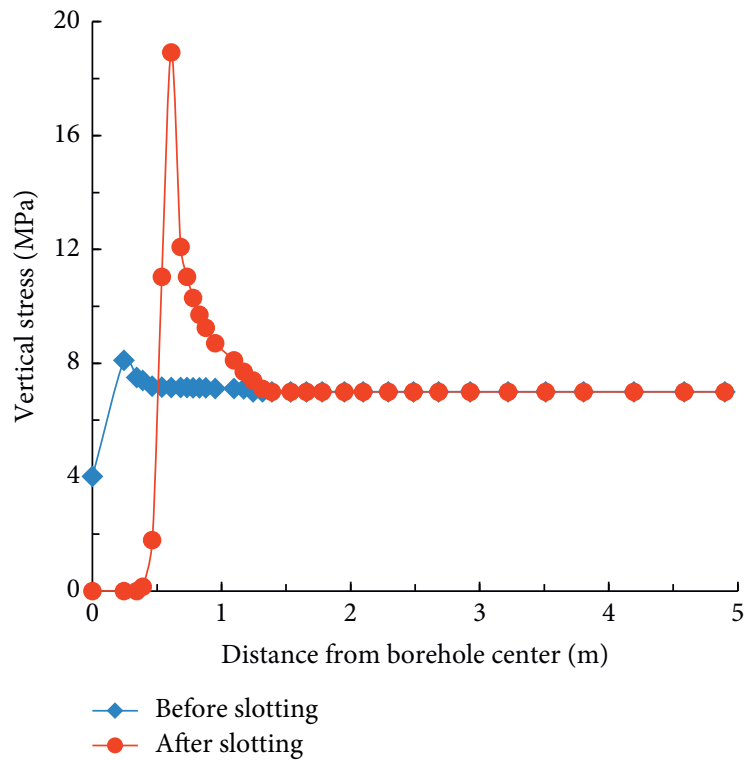

(b)

Figure 3: Vertical stress distribution on (a) $X=2 \mathrm{~cm}$ and (b) $Y=2 \mathrm{~cm}$ measured lines before and after slotting.

center of the slotting borehole to around in the vertical direction. The stress concentration occurs on the top of the borehole, and the maximum stress is $8.1 \mathrm{MPa}$, and the stress concentration factor is 1.1. After being slotted, a large-area stress relief appears with the influence scope of $6.4 \mathrm{~m}$. From
Figure 3(b), the vertical stress on $Y=2 \mathrm{~cm}$ measured line will increase gradually in radiation in the horizontal direction. A stress relief zone appears, of which the influence scope is $24 \mathrm{~cm}$. After being slotted, a stress concentration area was formed in the horizontal direction. Under the effect of 
concentrated stress, a certain yield zone appears at the end of slots, with maximum stress at $18.92 \mathrm{MPa}$.

Figure 4 shows the horizontal stress distribution on $X=2 \mathrm{~cm}$ and $Y=2 \mathrm{~cm}$ measured lines before and after slotting. From Figure 4(a), after the formation of the borehole, a small stress relief area with diameter of $9 \mathrm{~cm}$ appears around the borehole, and the minimum stress is 4.06 $\mathrm{MPa}$. After being slotted, the diameter of the stress relief area increases to $1.2 \mathrm{~m}$. From Figure 4(b), there also exists a stress relief area in the horizontal direction. Therefore, an obvious stress relief area with $6.4 \mathrm{~m} \times 1.2 \mathrm{~m}$ will be formed around the borehole after slotting.

\subsection{The Influence of Slotting Parameters on Stress Relief of the Coal Seam}

2.3.1. The Influence of Borehole Diameter on Stress Relief of the Coal Seam. To study the influence of borehole diameter on stress relief of the coal seam after slotting, the diameters of $84 \mathrm{~mm}, 100 \mathrm{~mm}, 120 \mathrm{~mm}$, and $150 \mathrm{~mm}$ were selected for simulation, respectively. The stress distribution of the coal seam after slotting is shown in Figures 5 and 6.

From Figures 5 and 6, the distribution of vertical stress and horizontal stress of the coal seam around the borehole with different diameters after slotting is basically same, which indicates that the diameter of the borehole has a small effect on the stress relief effect by hydraulic slotting. On the contrary, in the field gas extraction work, it is not necessary to drill large-diameter slotting boreholes, which can also reduce the drilling cost.

2.3.2. The Influence of Slotting Width on Stress Relief of the Coal Seam. To study the influence of slotting width on stress relief of the coal seam, the slotting widths of $40 \mathrm{~mm}, 60 \mathrm{~mm}$, $80 \mathrm{~mm}$, and $100 \mathrm{~mm}$ are selected for simulation, respectively. The stress distribution of the coal seam around slots with different slotting widths is shown in Figures 7 and 8. And, the corresponding stress relief area is shown in Table 2 .

It can be seen that, the larger the slotting width, the larger the stress relief area. So, if the slotting width increases to a certain value, the coal seam can be fully stress relieved so as to generate a fully connected fracture network, which provides excellent conditions for high-efficiency gas extraction. Therefore, the increase of slotting width is the key parameter to evaluate the performance of the high-pressure water jet slotting device. However, in the field work, the slotting width is restrained by many conditions, such as the pressure of the pump, slotting nozzle performance, and coal and rock strength. Therefore, the selection of slotting width should depend on the geological conditions and device performance, so as to achieve the best stress relief effect.

2.3.3. The Influence of Slotting Length on Stress Relief of the Coal Seam. To study the influence of slotting length on stress relief of the coal seam, the slotting lengths of $60 \mathrm{~cm}$, $90 \mathrm{~cm}$, and $120 \mathrm{~cm}$ are selected for simulation, respectively. The stress distribution of the coal seam around slots with different slotting lengths is shown in Figures 9 and 10. It can be seen that, within a small range of variation, the slotting length has little influence on the stress relief effect of the coal seam by using hydraulic slotting. Besides, the slotting length is also related to slotting system performance. And, the higher slotting length may trigger coal and gas outburst. So, it is not necessary to purely improve the slotting length.

\section{Field Experiments}

\subsection{Test Location and Scheme}

3.1.1. Test Equipment. The hydraulic slotting equipment mainly contains drilling bit, shallow spiral-integral drill rod, high-stress rotary aqua tail, water pump, remote operation floor, stress conversion slotter, high-stress hose, safety protection accessories, etc., and it can be seen in Figure 11. The device can realize the integration of drilling and slotting. The remote control is over 100 meters away from the slotting site, ensuring the safety and efficiency of the slotting process.

3.1.2. Hydraulic Slotting Process. The hydraulic slotting process mainly includes three stages: slotting preparation stage, borehole construction stage, and slotting stage. The operation process of hydraulic slotting can be seen from Figure 12. (1) Slotting preparation stage: before slotting, the water supply and power supply system should meet the requirement of the slotting operation. At the same time, the pumping pipe network and pumping metering device should be installed and completed in advance, and the hole sealing material should be prepared. In addition to this, drilling bit, slotting device drilling pipe, etc. are also assembled into the hydraulic slotting system in turn. All of this work is for the smooth operation of the slotting equipment. (2) Borehole construction stage: in this stage, low-pressure water is used to drill the borehole to the design depth. It is important to note that the sealing ring should be installed when connecting the drill pipe, and the thread of the drill pipe and its inner cavity should be cleaned. (3) Slotting stage: after the completion of drilling construction, it is necessary to remove the low-pressure water tail manually, connect the high-pressure water tail and high-pressure pipeline, and set up the warning line. Then, the water pump is turned on until water overflows through the borehole, at which time the drilling machine is turned on. Finally, slowly and uniformly adjust the pressure valve to the specified pressure value. At this time, the water flows through the high-pressure hose into the drill pipe, and the jet is formed by the nozzle on the slitter to cut the coal. The time of cutting the coal body is about 20-25 min each time. After the end of each knife slit, the pump is pressed back to zero and then shut down. According to the set slit spacing, the backward slit operation method is used to continue until the slit is completed.

3.1.3. Test Location and Scheme. The test mine selected is in Sangshuping NO.2 coal mine in Hancheng City, Shanxi Province, which is a coal and gas outburst mine. This extraction seam is $3 \#$ coal seam, with average thickness of 


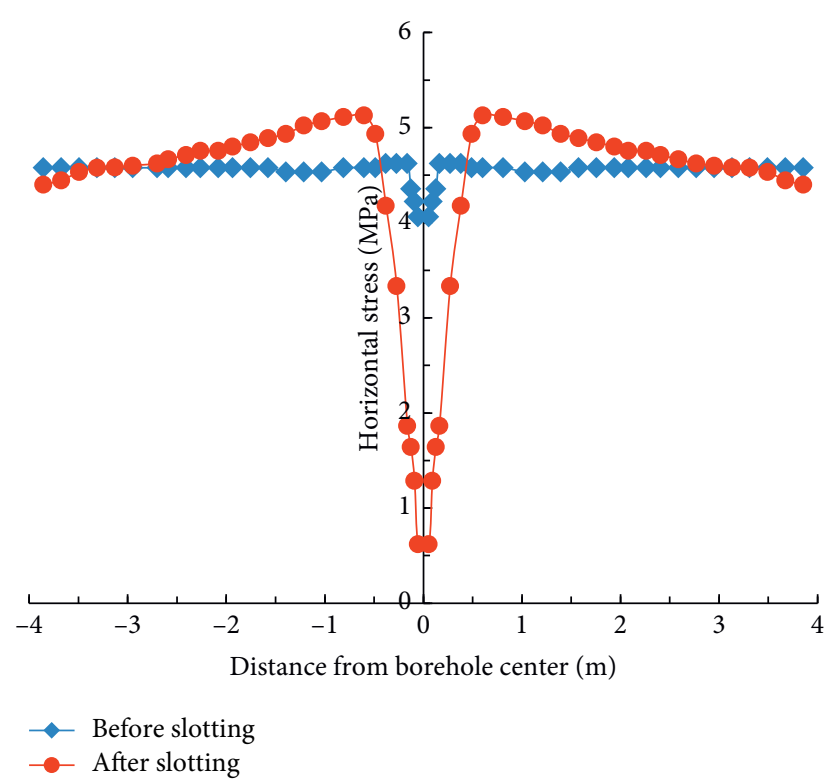

(a)

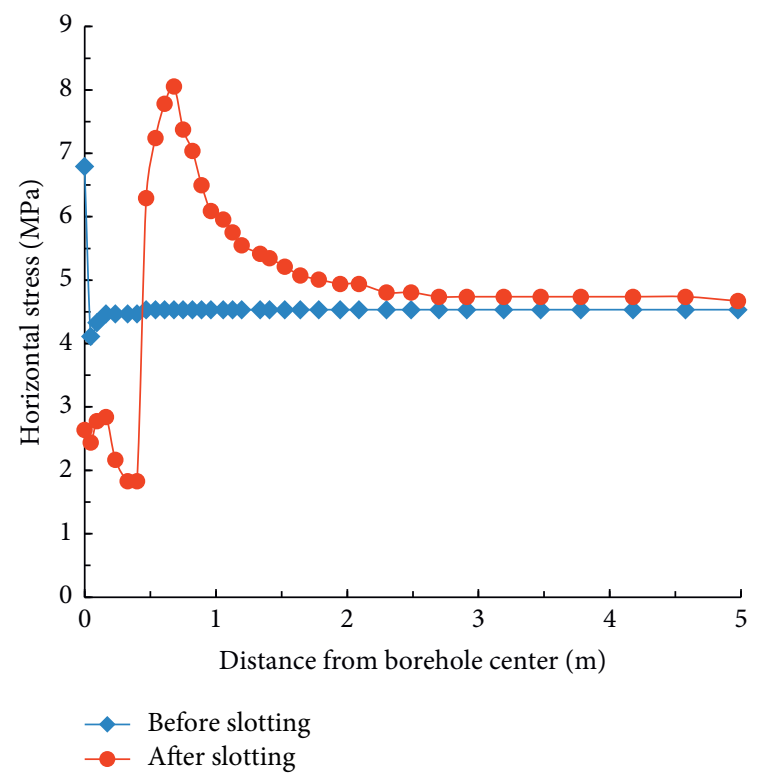

(b)

Figure 4: Horizontal stress distribution on (a) $X=2 \mathrm{~cm}$ and (b) $Y=2 \mathrm{~cm}$ measured lines before and after slotting.

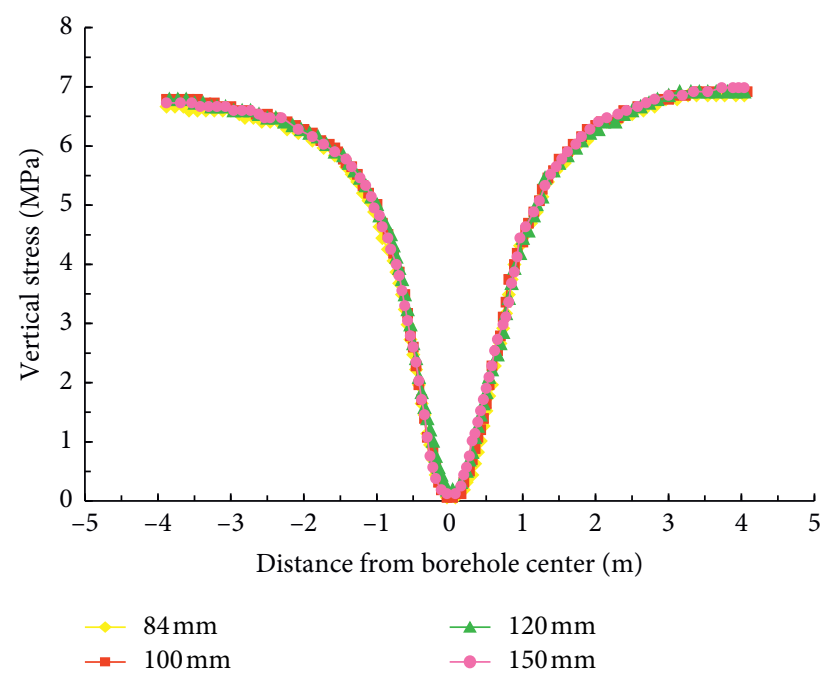

(a)

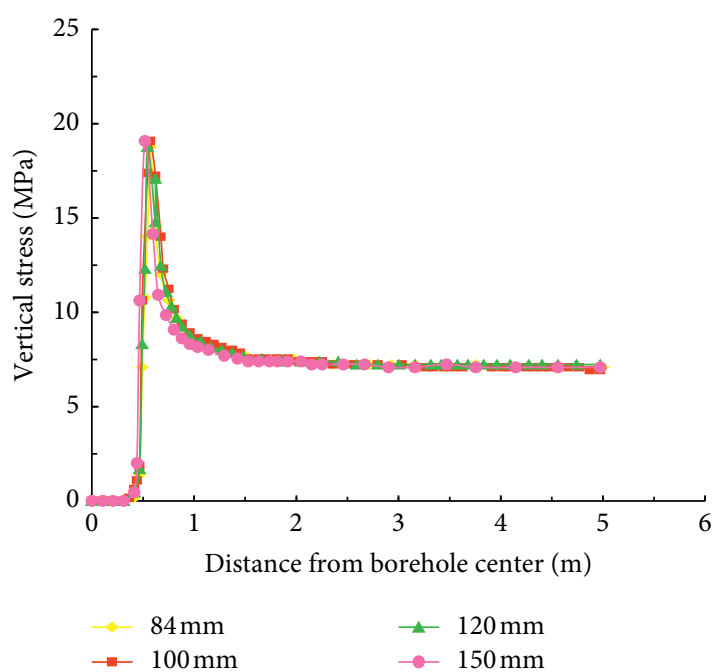

(b)

Figure 5: Vertical stress distribution on (a) $X=2 \mathrm{~cm}$ and (b) $Y=2 \mathrm{~cm}$ measured lines after slotting.

$5.97 \mathrm{~m}$, gas pressure of $0.4-0.94 \mathrm{MPa}$, and gas content of $8-14.57 \mathrm{~m}^{3} /$ t. The mine mainly adopted gas preextraction by bedding boreholes. However, due to the high gas content and poor permeability of the coal seam, the gas extraction efficiency cannot reach the expected effect. And, there are still some dynamic phenomena occurring in the drilling process, such as spraying hole and clamping drill, which seriously restrict the safe and efficient production of the mine.

The test site is located in the 3306 working face, where the coal seam thickness is $4.35 \mathrm{~m} \sim 6.16 \mathrm{~m}$, the coal seam sturdiness coefficient is $0.4 \sim 0.5$, and the destruction of the coal type is class II. The maximum original gas content of
No. 3 coal seam measured in the test area is $12.24 \mathrm{~m}^{3} / \mathrm{t}$, which indicates that the test area has a high risk of coal and gas outburst. The coal seam geological conditions of the working face improve the favorable conditions for the hydraulic slotting test [42].

16 bedding boreholes were drilled in this test. The boreholes are divided into two groups for comparison of the test results, where $S_{1}-S_{8}$ are slotting boreholes and $D_{1}-D_{8}$ are ordinary boreholes. Through the comprehensive consideration of the numerical simulation research and the actual conditions on-site, the optimized hydraulic slotting technological parameters were determined, that is, the drilling diameter was $90 \mathrm{~mm}$, the drilling depth was $80 \mathrm{~m}$, the 


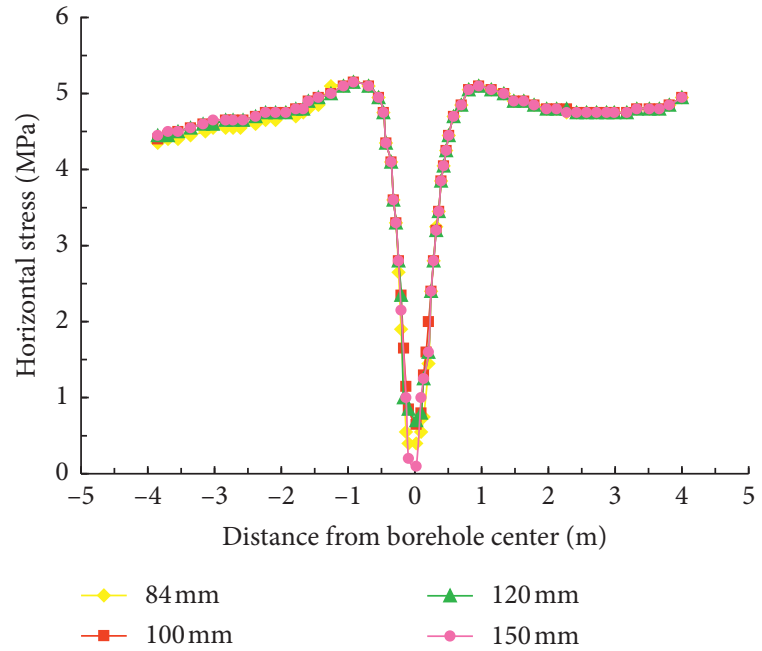

(a)

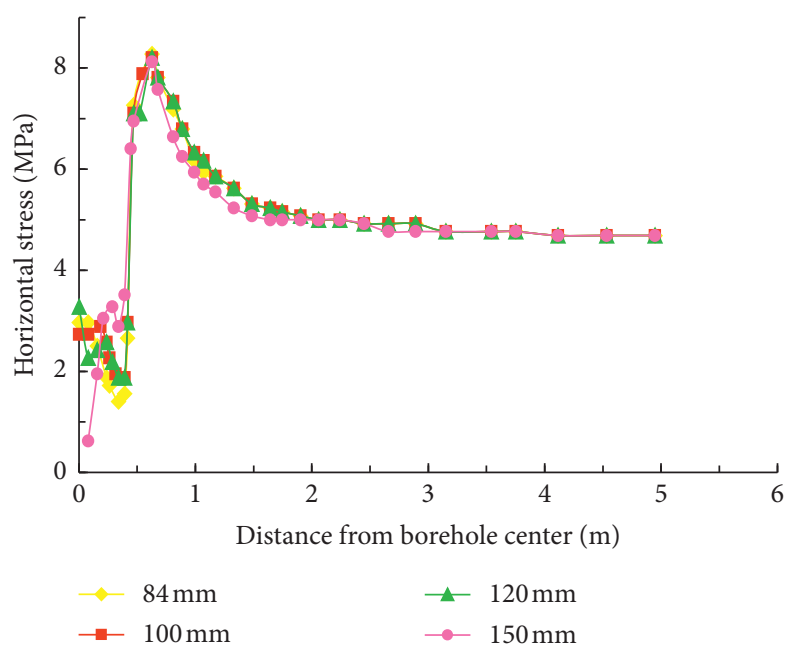

(b)

Figure 6: Horizontal stress distribution on (a) $X=2 \mathrm{~cm}$ and (b) $Y=2 \mathrm{~cm}$ measured lines after slotting.

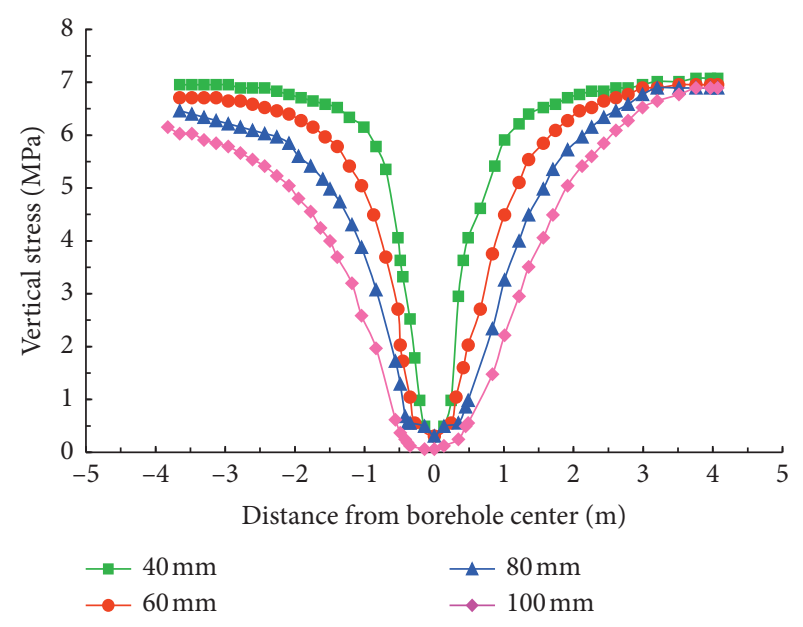

(a)

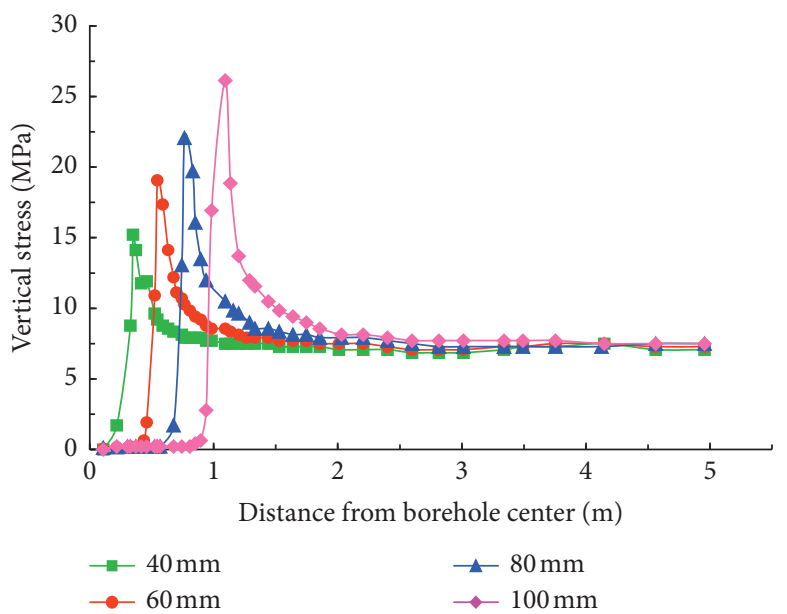

(b)

Figure 7: Vertical stress distribution after slotting. (a) $X=2 \mathrm{~cm}$. (b) $Y=2 \mathrm{~cm}$.

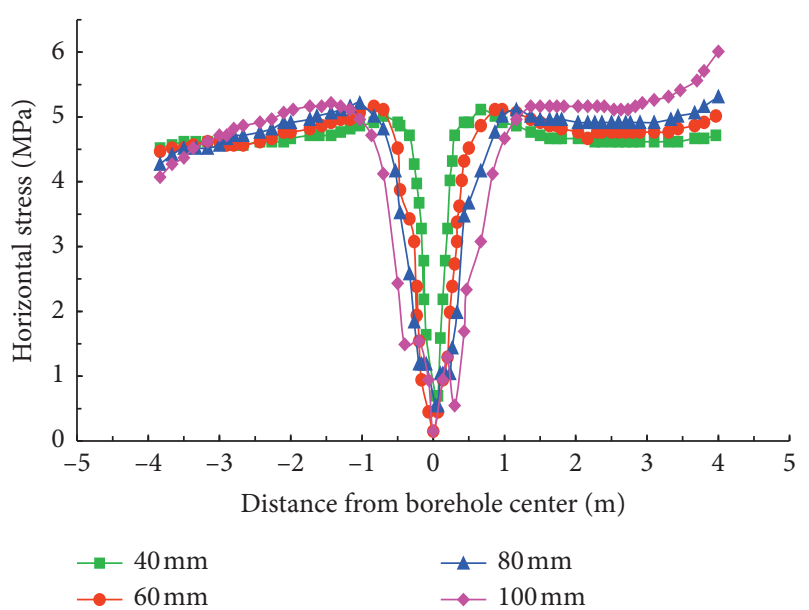

(a)

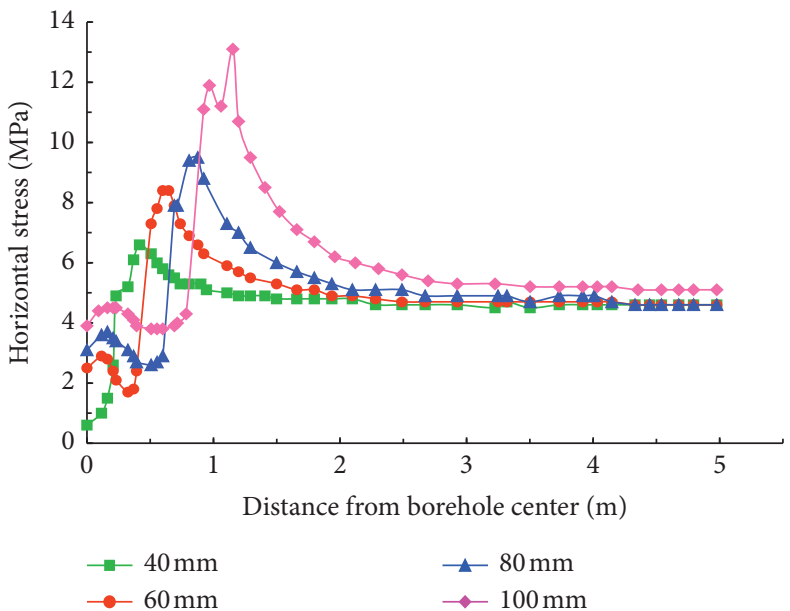

(b)

Figure 8: Horizontal stress distribution after slotting. (a) $X=2 \mathrm{~cm}$. (b) $Y=2 \mathrm{~cm}$. 
TABLE 2: Stress relief area around slotting.

\begin{tabular}{lcccc}
\hline \multirow{2}{*}{ Slotting width $(\mathrm{mm})$} & \multicolumn{2}{c}{ Stress relief area of vertical stress } & \multicolumn{2}{c}{ Stress relief area of horizontal stress } \\
& Slotting up-down side $(\mathrm{cm})$ & Slotting end $(\mathrm{cm})$ & Slotting up-down side $(\mathrm{cm})$ & Slotting end $(\mathrm{cm})$ \\
\hline 40 & 2.2 & 0.4 & 0.4 & 0.4 \\
60 & 3.2 & 0.6 & 0.6 & 0.6 \\
80 & 3.5 & 0.8 & 0.9 & 0.8 \\
100 & 3.8 & 1.0 & 1.2 & 1.0 \\
\hline
\end{tabular}
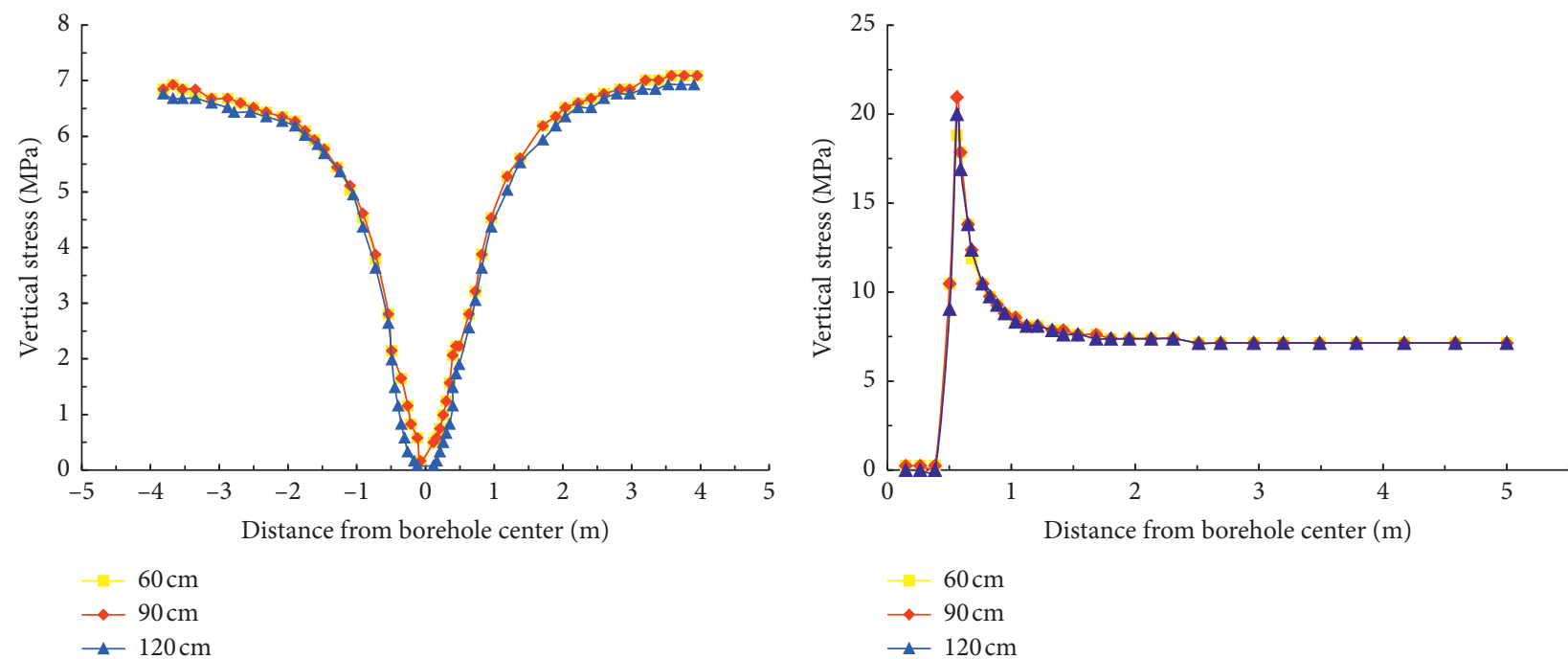

(a)

(b)

Figure 9: Vertical stress distribution after slotting. (a) $X=2 \mathrm{~cm}$. (b) $Y=2 \mathrm{~cm}$.

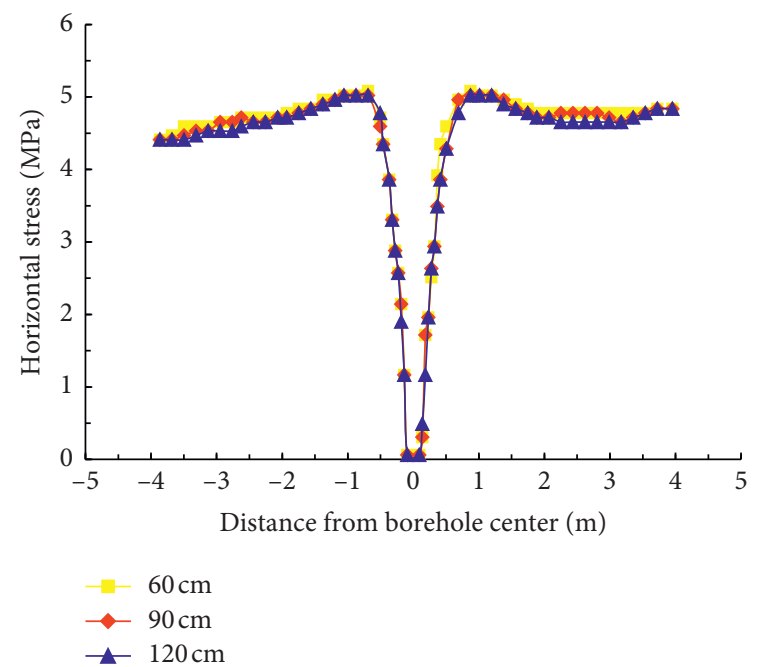

(a)

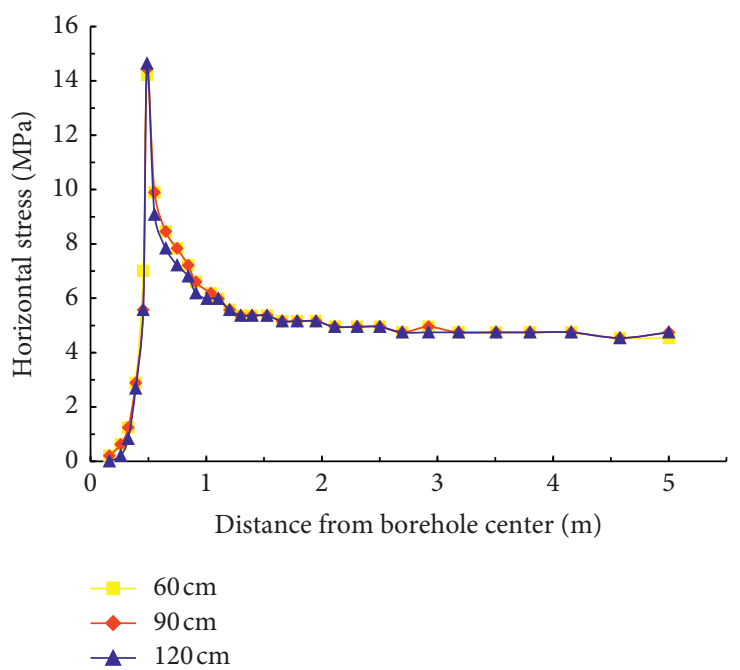

(b)

Figure 10: Horizontal stress distribution after slotting. (a) $X=2 \mathrm{~cm}$. (b) $Y=2 \mathrm{~cm}$. 


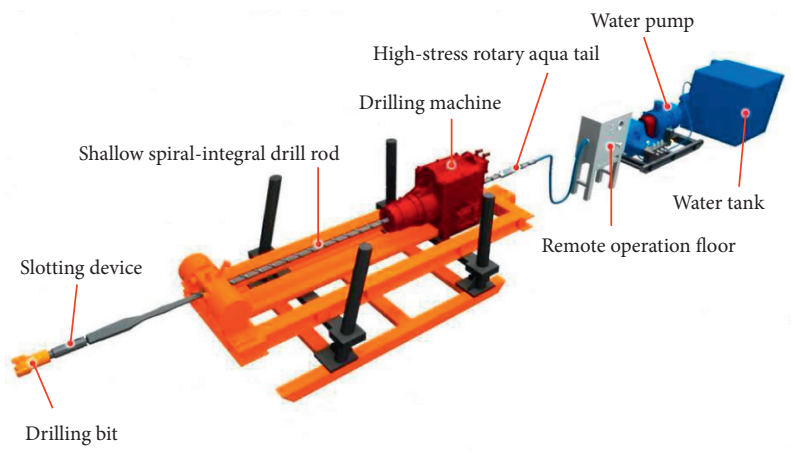

FIgURE 11: High-stress water jet slotting set device diagram.
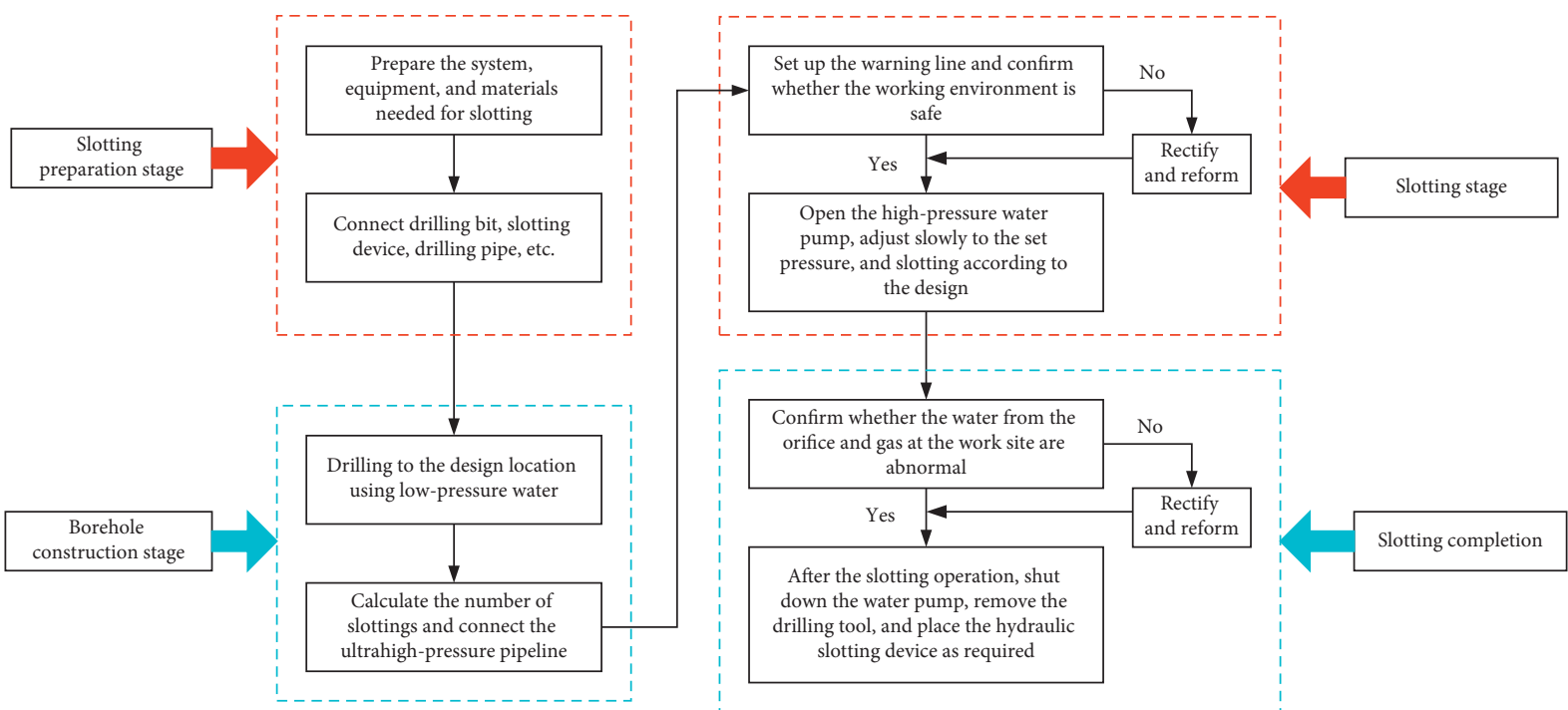

Figure 12: Operation process of hydraulic slotting.

drilling spacing was $12 \mathrm{~m}$, the hole sealing depth was $12 \mathrm{~m}$, the slotting length was $1.2 \mathrm{~m}$, the slotting width was $6 \mathrm{~cm}$, and the slotting spacing was $1 \mathrm{~m}$ [43]. The test site and boreholes' arrangement can be seen in Figure 13.

\subsection{Results and Analysis}

3.2.1. The Natural Gas Flow and Attenuation Coefficient in Boreholes. The better the cutting effect of hydraulic slotting, the greater the permeability of the coal seam, the greater the initial gas flow of the borehole. The natural gas flow is an important index to characterize the initial gas permeability. Therefore, before connecting the drainage pipeline with the borehole, the natural gas flow of the slotted borehole and the ordinary borehole was measured, respectively. The measurement results are shown in Figure 14.

Figure 14 shows that natural gas flow in drill holes $S_{1} \sim S_{8}$ is $0.0203-0.0813 \mathrm{~m}^{3} /(\mathrm{min} \cdot \mathrm{hm})$; natural gas flow in drill holes $D_{1}-D_{8}$ is $0.0052 \sim 0.0363 \mathrm{~m}^{3} /(\mathrm{min} \cdot \mathrm{hm})$. The natural gas flow in drill holes rises 3-4 times averagely after hydraulic slotting. It can be seen that the permeability of the coal seam has been significantly improved in the initial stage after the completion of hydraulic slotting. On the one hand, the

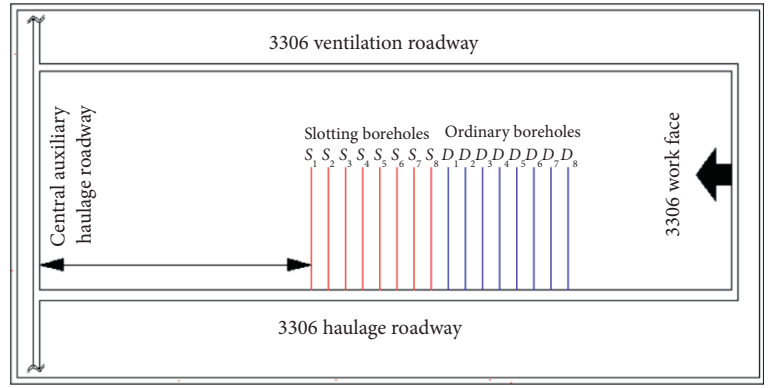

Figure 13: Test site and borehole arrangement.

hydraulic slotting causes the pressure relief of coal around the borehole, resulting in a large number of new fractures and secondary fractures. On the other hand, slotted stress in the coal body around the borehole is reduced, and the compression of the original coal crack opening increases. Both of them jointly promote the connection of the fracture network around the borehole and provide favorable conditions for gas migration. In addition, the slotting increases the exposed area of coal and accelerates the gas desorption speed, which is also an important reason for increasing the gas flow in the borehole. 


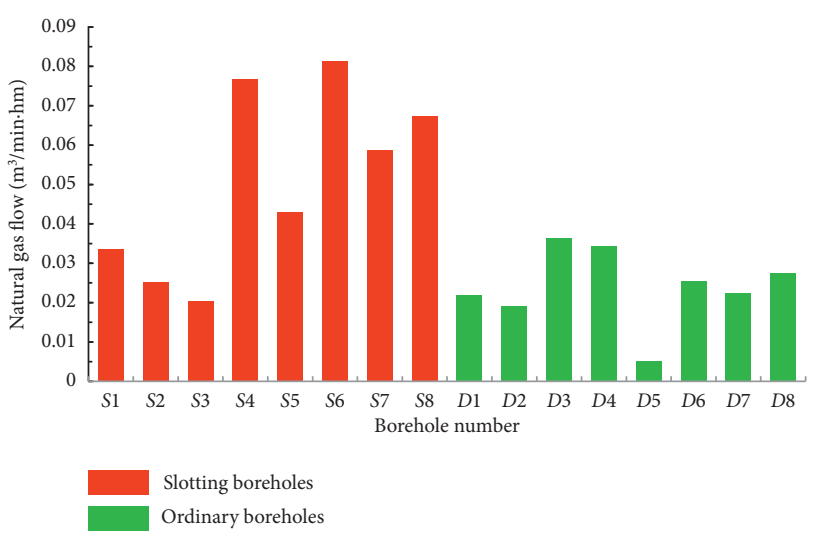

FIGURE 14: Comparison graph of the natural gas flow in slotting boreholes and ordinary boreholes.

The attenuation coefficient of the gas flow in the borehole is an important index to evaluate the difficulty of gas extraction in the coal seam. The larger the attenuation coefficient is, the harder gas exhausting and mining may be. This paper selects $S_{6}$ and $S_{7}$ and $D_{7}$ and $D_{8}$ drill holes, respectively, to measure gas emission initial velocity and obtain the attenuation coefficient of drill holes' gas flow by mathematical fitting. The results are shown in Figure 15.

From Figure 15, it can be seen that, with the extension of time, the gas emission initial velocity of each borehole shows a decreasing trend, but the extent of reduction of the slotted borehole is significantly higher than that of the ordinary drilling hole. In addition, the attenuation coefficients of the gas flow of slotting boreholes $S_{6}$ and $S_{7}$ are $0.0215 \mathrm{~d}^{-1}$ and $0.0237 \mathrm{~d}^{-1}$, respectively. And, the attenuation coefficients of the gas flow of ordinary boreholes $D_{7}$ and $D_{8}$ are $0.0763 \mathrm{~d}^{-1}$ and $0.1231 \mathrm{~d}^{-1}$, respectively. That is, the attenuation coefficient of the gas flow of slotting boreholes is $1 / 6-1 / 3$ times smaller than that of ordinary boreholes. This is because, under the action of effective stress, the opening degree of slotted fracture gradually decreases or even closes, and the permeability of the coal seam is restrained. However, for ordinary boreholes, the number of cracks produced by coal relief around boreholes is limited, and the closure of cracks under effective stress is also small. It also shows that the effect of hydraulic slotting on coal seam permeability is more significant than that of borehole pressure relief.

3.2.2. Improvement Effect of Gas Extraction Quantity by Hydraulic Slotting. The gas extraction purity is an important parameter to indicate the gas extraction effect. The higher the gas extraction purity is, the lower the residual gas content of the coal seam will be, which is of great significance to reduce or even eliminate the coal seam outburst risk. To analyze the improvement effect of gas extraction quantity by hydraulic slotting, the maximum and average values of daily gas extraction quantity of slotting boreholes and ordinary boreholes are counted, as shown in Figure 16. The maximum and average gas extraction quantities of slotting boreholes are $133.1 \mathrm{~m}^{3} / \mathrm{d}$ and $93.0 \mathrm{~m}^{3} / \mathrm{d}$, respectively. And, the maximum and average gas extraction quantities of ordinary boreholes are $66.7 \mathrm{~m}^{3} / \mathrm{d}$
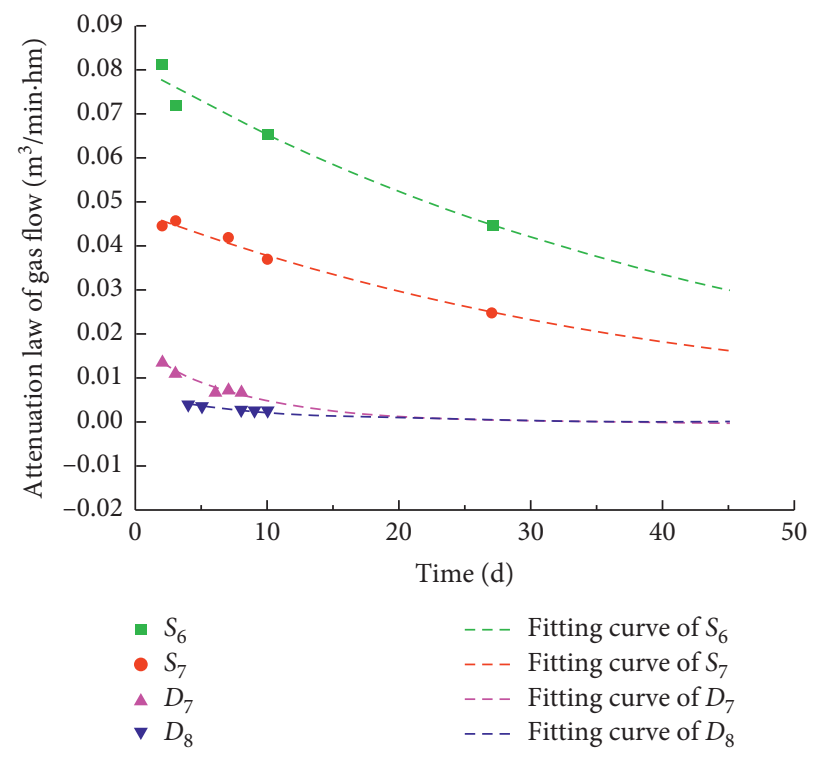

\begin{tabular}{|l|c|c|c|}
\hline \multirow{2}{*}{$\begin{array}{l}\text { Borehole } \\
\text { number }\end{array}$} & \multicolumn{3}{|c|}{$Y=a^{*} \exp \left(b^{*} X\right)$} \\
\cline { 2 - 4 } & $a$ & $b$ & $R^{2}$ \\
\hline$S_{6}$ & 0.0814 & -0.0221 & 0.9396 \\
\hline$S_{7}$ & 0.0438 & -0.024 & 0.9802 \\
\hline$D_{7}$ & 0.0169 & -0.1259 & 0.9268 \\
\hline$D_{8}$ & 0.0056 & -0.0817 & 0.981 \\
\hline
\end{tabular}

FIgURE 15: The attenuation law of the gas flow of slotting and ordinary boreholes.

and $40.4 \mathrm{~m}^{3} / \mathrm{d}$, respectively. Thus, the gas quantity of slotting boreholes is 2-3 times higher than that of ordinary boreholes.

3.2.3. Effective Gas Extraction Radius by Hydraulic Slotting. Before the high-pressure hydraulic slotting test, the maximum original gas content measured in the test area was $12.24 \mathrm{~m}^{3} / \mathrm{t}$. According to the requirements of China's coal industry, the gas content in the test area should be reduced to less than $8 \mathrm{~m}^{3} / \mathrm{t}$ to meet the drainage standard, which is also 


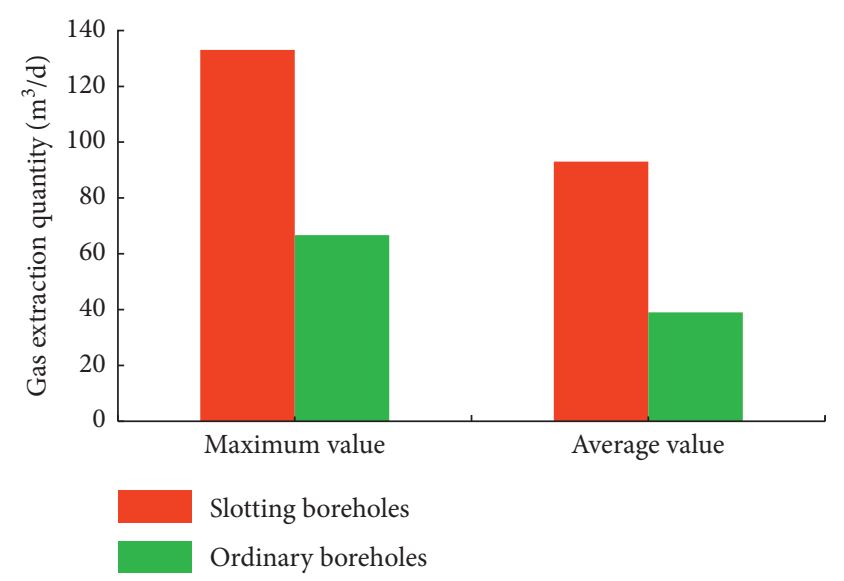

Figure 16: Daily gas extraction quantity of slotting boreholes and ordinary boreholes.

the criterion for determining the effective drainage radius. According to the measured data, the steps to calculate the extraction radius are as follows:

(1) Calculate the total amount of gas extraction in the test area, and the formula is as follows:

$$
Q_{t}=L_{1} \times L_{2} \times h \times \gamma \times W \times \eta,
$$

where $L_{1}$ is the length of the extraction hole control area, $m, L_{2}$ is the width of the extraction hole control area, $m, h$ is average thickness of the coal seam, $m, \gamma$ is volume density of coal, $\mathrm{t} / \mathrm{m}^{3}, W$ is coal seam gas content, $\mathrm{m}^{3} / \mathrm{t}$, and $\eta$ is the gas extraction rate, $\%$

(2) Calculate the number of boreholes required to reach the standard of extraction under a certain time, and the formula is as follows:

$$
N=\frac{Q_{t}}{Q_{s}},
$$

where $Q_{2}$ is the total amount of single-hole gas extraction in a certain time, $\mathrm{m}^{3}$

(3) Calculate the effective radius of drilling drainage, and the formula is as follows:

$$
r=\frac{L}{2 N K}
$$

where $L$ is the equivalent extraction length of the extraction area, $m$, and $K$ is the unbalance coefficient of the borehole layout, and the value ranges from 1.0 to 1.3

According to the above calculation process, the results of the extraction radius of the slotted hole and the ordinary hole are shown in Figure 17. It can be seen that the effective gas extraction radius of ordinary boreholes after 30 days, 60 days, 90 days, and 180 days is $0.32 \mathrm{~m}, 0.6 \mathrm{~m}, 0.84 \mathrm{~m}$, and $1.36 \mathrm{~m}$, respectively; while, the effective gas extraction radius of slotting boreholes after 30 days, 60 days, 90 days, and 180 days is $0.8 \mathrm{~m}$, $1.25 \mathrm{~m}, 1.75 \mathrm{~m}$, and $1.36 \mathrm{~m}$. Therefore, the effective gas extraction radius of slotting boreholes is 2-3 times larger than that of ordinary boreholes.

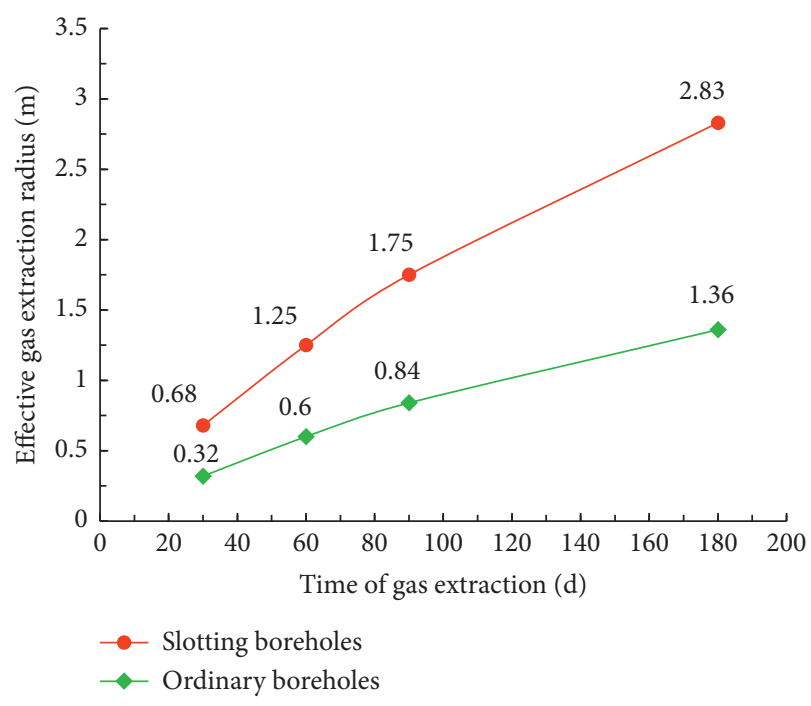

FIGURE 17: Effective gas extraction radius of slotting boreholes and ordinary boreholes.

\section{Conclusion}

(1) The stress distribution around the borehole before and after slotting is analyzed. Before slotting, a small area of stress relief appeared around the boreholes, and a circle caused by stress concentration was formed. After slotting, the stress of the coal seam around the borehole is fully released, and even though the slotting width is only $6 \mathrm{~cm}$, an obvious stress relief area with $6.4 \mathrm{~m} \times 1.2 \mathrm{~m}$ would be formed around boreholes.

(2) The influence of slotting parameters on the stress relief of the coal seam was studied. The slotting width has great influence on the stress relief effect, while the borehole diameter and slotting length have little influence on the stress relief effect.

(3) Field results showed that the gas extraction efficiency was highly enhanced by hydraulic slotting. The natural gas flow of slotting boreholes rises 3-4 times averagely. The attenuation coefficient of the gas flow of slotting boreholes is $1 / 6-1 / 3$ times smaller than that of ordinary boreholes. And, the gas extraction quantity and effective gas extraction radius are improved 2-3 times by hydraulic slotting, respectively.

\section{Data Availability}

The data used to support the findings of the study are included within this article.

\section{Conflicts of Interest}

The authors declare that they have no conflicts of interest.

\section{Acknowledgments}

This work was supported by the National Key R\&D Program of China (2018YFC0808305). 


\section{References}

[1] H. Xie, L. Wu, and D. Zhang, "Prediction on the energy consumption and coal demand of China in 2025," Journal of China Coal Society, vol. 44, no. 7, pp. 1949-1960, 2019, in Chinese.

[2] L. Yuan, "Control of coal and gas outbursts in huainan mines in China: a review," Journal of Rock Mechanics and Geotechnical Engineering, vol. 8, no. 4, pp. 559-567, 2016.

[3] L. Yuan, "Strategic thinking of simultaneous exploitation of coal and gas in deep mining," Journal of China Coal Society, vol. 44, no. 1, pp. 1-6, 2016, in Chinese.

[4] H. Chen, Z. Wang, X. Chen, X. Chen, and L. Wang, "Increasing permeability of coal seams using the phase energy of liquid carbon dioxide," Journal of $\mathrm{CO}_{2}$ Utilization, vol. 19, pp. 112-119, 2017.

[5] F. Yan, J. Xu, S. Peng, Q. Zou, Q. Long, and Z. Zhao, "Effect of capacitance on physicochemical evolution characteristics of bituminous coal treated by high-voltage electric pulses," Powder Technology, vol. 367, pp. 47-55, 2020.

[6] X. Gao, J. Liu, C. Zhang, and C. Zhang, "Experimental study on permeability improvement of deep hole pre-splitting cumulative blasting in low permeability coal seam," Safe in Coal Mines, vol. 60, no. 4, pp. 23-26, 2019, in Chinese.

[7] Z. Ti, F. Zhang, J. Pan, X. Ma, and Z. Shang, "Permeability enhancement of deep hole pre-splitting blasting in the low permeability coal seam of the Nanting coal mine," PLoS One, vol. 13, no. 6, Article ID e0199835, 2018.

[8] C. G. Huang, Y. B. Zhang, J. F. He, Y. Luo, and Z. G. Sun, "Permeability improvements of an outburst-prone coal seam by means of presplitting and blasting with multiple deep boreholes," Energy Science \& Engineering, vol. 7, no. 5, pp. 2223-2236, 2019.

[9] C. Shen, B. Lin, C. Sun, Q. Zhang, and Q. Li, "Analysis of the stress-permeability coupling property in water jet slotting coal and its impact on methane drainage," Journal of Petroleum Science and Engineering, vol. 126, pp. 231-241, 2015.

[10] T. Lu, H. Yu, T. Zhou, J. Mao, and B. Guo, "Improvement of methane drainage in high gassy coal seam using waterjet technique," International Journal of Coal Geology, vol. 79, no. 1-2, pp. 40-48, 2009.

[11] H. Chi, G. Li, H. Liao, S. Tian, and X. Song, "Effects of parameters of self-propelled multi-orifice nozzle on drilling capability of water jet drilling technology," International Journal of Rock Mechanics and Mining Sciences, vol. 86, pp. 23-28, 2016.

[12] B. Lin and C. Shen, "Coal permeability-improving mechanism of multilevel slotting by water jet and application in coal mine gas extraction," Environmental Earth Sciences, vol. 73, no. 10, pp. 5975-5986, 2015.

[13] F. Yan, B. Lin, C. Zhu et al., "A novel ECBM extraction technology based on the integration of hydraulic slotting and hydraulic fracturing," Journal of Natural Gas Science and Engineering, vol. 22, pp. 571-579, 2015.

[14] W. Lu and B. Huang, "Mathematical model of methane driven by hydraulic fracturing in gassy coal seams," Adsorption Science \& Technology, vol. 38, no. 3-4, pp. 127-147, 2020.

[15] J. Jiang, W. Yang, Y. Cheng, B. Lv, K. Zhang, and K. Zhao, "Application of hydraulic flushing in coal seams to reduce hazardous outbursts in the mengjin mine, China," Environmental and Engineering Geoscience, vol. 24, no. 4, pp. 425440, 2018.

[16] W. Feng, X. Su, J. Wang, J. Qin, and X. Li, “The mechanism and field test of permeability improvement by hydraulic flushing in three-soft and single coal seam," Coal Geology \& Exploration, vol. 43, no. 1, pp. 100-103, 2015, in Chinese.

[17] Y. Tao, C. Zhang, J. Xu, S. Peng, and D. Feng, "Effect evaluation on stress relief and permeability improvement of hydraulic flushing physical experiment," Journal of Chongqing University, vol. 41, no. 10, pp. 69-77, 2018, in Chinese.

[18] X. Wei, P. Massarotto, G. Wang, V. Rudolph, and S. D. Golding, " $\mathrm{CO}_{2}$ sequestration in coals and enhanced coalbed methane recovery: new numerical approach," Fuel, vol. 89, no. 5, pp. 1110-1118, 2010.

[19] X. Zhang and P. G. Ranjith, "Experimental investigation of effects of $\mathrm{CO}_{2}$ injection on enhanced methane recovery in coal seam reservoirs," Journal of $\mathrm{CO}_{2}$ Utilization, vol. 33, pp. 394-404, 2019.

[20] Z. Hong, C. Wang, and Z. Xiong, "Research on $\mathrm{CO}_{2}$ phasetransition fracturing technology for permeability improvement in high gas and low permeability coal seam," Journal of Safety Science and Technology, vol. 13, no. 1, pp. 39-45, 2017, in Chinese.

[21] X. Yang, G. Wen, H. Sun et al., "Environmentally friendly techniques for high gas content thick coal seam stimulation-multi-discharge $\mathrm{CO}_{2}$ fracturing system," Journal of Natural Gas Science and Engineering, vol. 61, pp. 71-82, 2019.

[22] H. Yang, Study on Mechanism and Characteristics Laws of Displacement Coalbed Methane by Underground Gas Injection, Henan Polytechnic University, Jiaozuo, China, 2010.

[23] Z. Yang, L. Dou, C. Liu, M. Xu, Z. Lei, and Y. Yao, “Application of high-pressure water jet technology and the theory of rock burst control in roadway," International Journal of Mining Science and Technology, vol. 26, no. 5, pp. 929-935, 2016.

[24] X. Zhang, Y. Pan, and Z. Li, "A study of rock burst prevention by high-pressure water jet applied to cutting coal seam," Science Technology and Engineering, vol. 10, no. 6, pp. 15141516, 2010, in Chinese.

[25] L. Yin, Y. Pan, Z. Li, and S. Wang, "Numerical simulation of rock burst prevention by high-pressure water jet applied to cutting coal seam," Science Technology and Engineering, vol. 10 , no. 5 , pp. $1225-1230,2010$, in Chinese.

[26] K. Feng, "Research on the application of hydraulic pressure relived and permeability enhanced technology in cross-cut rapid uncovering coal," Mining Safety \& Environmental Protection, vol. 47 , no. 4, pp. $62-65,2020$, in Chinese.

[27] Y. Lu, Z. Ge, X. Li, J. Chen, and Y. Liu, "Investigation of a selfexcited pulsed water jet for rock cross-cutting to uncover coal," Journal of China University of Mining \& Technology, vol. 39, no. 1, pp. 55-58, 2010, in Chinese.

[28] W. Xiong, "Numerical study and application of pressure relief and permeability enhancement technology for hydraulic cutting of tunnel uncovering coal," China Journal of Underground Space and Engineering, vol. 16, no. S1, pp. 291-296, 2020, in Chinese.

[29] B. Lin, F. Yan, C. Zhu et al., "Cross-borehole hydraulic slotting technique for preventing and controlling coal and gas outbursts during coal roadway excavation," Journal of Natural Gas Science and Engineering, vol. 26, pp. 518-525, 2015.

[30] M. Chen, B. Li, C. Li, and X. Pang, "Application of hydraulic slotting as an outburst prevention technology in driving face," China Coal, vol. 36, no. 5, pp. 96-98, 2010, in Chinese.

[31] J. Wei, Study on Hydraulic Gas Control Technology of Roadway Tunneling, Chongqing University, Chongqing, China, 2017, in Chinese.

[32] Y. Lu, C. Huang, Y. Jia, Y. You, and J. Tang, "Analysis on rock cross-cut coal uncovering using high stress water jet slotting 
in close distance seam group," Journal of Chongqing University, vol. 37, no. 3, pp. 95-100, 2014, in Chinese.

[33] Y. Zhang and Q. Zou, "A prediction model for the slot depth of high pressure water jet," Results in Physics, vol. 11, pp. 1105-1109, 2018.

[34] Y. Cheng, J. Zhao, C. Guo, X. Zhang, and W. Zhang, "Study on deep forecasting model of ultra high stress abrasive water jet drilling," Coal Mine Machinery, vol. 37, pp. 66-68, 2016.

[35] G. Si, S. Durucan, J. Shi, A. Korre, and W. Cao, "Parametric analysis of slotting operation induced failure zones to stimulate low permeability coal seams," Rock Mechanics and Rock Engineering, vol. 1, no. 52, pp. 163-182, 2019.

[36] T.-K. Lu, F.-T. Chang, Z.-F. Wang, and P.-J. Yuan, "Numerical modeling of time-dependent closure of coal seam artificial fractures," Journal of Coal Science and Engineering (China), vol. 19, no. 4, pp. 441-453, 2013.

[37] T. Lu, Z. Wang, H. Yang, P. Yuan, Y. Han, and X. Sun, "Improvement of coal seam gas drainage by under-panel cross-strata stimulation using highly pressurized gas," International Journal of Rock Mechanics and Mining Sciences, vol. 77, pp. 300-312, 2015.

[38] Y. Xue, F. Gao, Y. Gao, X. Liang, Z. Zhang, and Y. Xing, "Thermo-hydro-mechanical coupled mathematical model for controlling the pre-mining coal seam gas extraction with slotted boreholes," International Journal of Mining Science and Technology, vol. 27, no. 3, pp. 473-479, 2017.

[39] Z. Ge, X. Mei, Y. Jia, Y. Lu, and B. Xia, "Influence radius of slotted borehole drainage by high pressure water jet," Journal of Mining \& Safety Engineering, vol. 31, no. 4, pp. 657-664, 2014.

[40] Y. Xue, T. Teng, F. Dang, Z. Ma, S. Wang, and H. Xue, "Productivity analysis of fractured wells in reservoir of hydrogen and carbon based on dual-porosity medium model," International Journal of Hydrogen Energy, vol. 45, pp. 20240-20249, 2020.

[41] X. Kong, E. Wang, X. Liu et al., "Coupled analysis about multifactors to the effective influence radius of hydraulic flushing: application of response surface methodology," Journal of Natural Gas Science and Engineering, vol. 32, pp. 538-548, 2016.

[42] W. Long, S. Sun, K. Zheng, B. Wang, and X. Hei, "Probe into geological condition adaptability in coal seam high pressure hydraulic slotting permeability enhancement," Coal Geology of China, vol. 29, no. 3, pp. 37-40, 2017.

[43] Y. Zhang, Z. Huang, and C. Li, "Investigation and application of high pressure water jet annularity slotting self pressure release mechanism," Journal of China Coal Society, vol. 43, no. 11, pp. 3016-3022, 2018. 